\title{
Alienating Rhetoric in the Book of Lord Shang and its Moderation
}

Rhétorique de la provocation dans le Livre du Seigneur Shang

《商君書》中的“疏離性”修辭及其缓和

\section{Yuri Pines}

\section{(2) OpenEdition}

\section{Journals}

Electronic version

URL: http://journals.openedition.org/extremeorient/254

DOI: 10.4000/extremeorient.254

ISSN: 2108-7105

Publisher

Presses universitaires de Vincennes

Printed version

Date of publication: 1 November 2012

Number of pages: $79-110$

ISBN: 978-2-84292-352-5

ISSN: 0754-5010

\section{Electronic reference}

Yuri Pines, "Alienating Rhetoric in the Book of Lord Shang and its Moderation », Extrême-Orient ExtrêmeOccident [Online], 34 | 2012, Online since 01 November 2015, connection on 21 April 2019. URL : http:// journals.openedition.org/extremeorient/254; DOI : 10.4000/extremeorient.254 


\title{
Alienating Rhetoric in the Book of Lord Shang and its Moderation
}

\author{
Yuri Pines ${ }^{1}$
}

Shang Yang (d. 338 BCE) occupies a special place in China's intellectual history. Few if any thinkers have generated such intense antagonism as he did; few were so overwhelmingly identified as enemies of morality. While to a certain extent these negative views applied to all those thinkers whom we often dub the "Legalists," it seems that Shang Yang was often singled out as an exceptional scoundrel. Thus, in the Lüshi chunqiu - a syncretic text that rarely attacks individual thinkers - Shang Yang's deeds are presented, ominously, in the chapter named "Unrighteous" ("Wuyi"); while Sima Qian ends his biography of Shang Yang with an unusually explicit negation of his protagonist, who "deserved his ill fame." ${ }^{3}$ It seems that neither the thinkers' recognition of Shang Yang's achievements in Qin, nor possible sympathy toward him as a victim of unjust execution, sufficed to improve his reputation. ${ }^{4}$ Su Shi's (1036-1101)

1. This research was supported by the Israel Science Foundation (grant no. 511/11) and by the Michael William Lipson Chair in Chinese Studies. It was first presented at the conference "Rhetoric as a Political Tool in Early China," Jerusalem, May 2011. I am indebted to the conference participants, especially to Paul van Els and David Schaberg, as well as to Extrême-Orient, Extrême-Occident anonymous reviewers for their insightful comments on the earlier version of this paper.

2. From the Han dynasty on, it became fashionable to blame a group of thinkers, such as Shang Yang, Shen Buhai (d. 337 BCE) and Han Feizi (d. 233 BCE) as responsible for "forcibly imposing the five punishments, employing slicing and amputations and turning their backs on the fundamentals of the Way and its Potency" (Major et al.2010: $6,230)$. In the later tradition these thinkers were usually identified as "Legalists"; for the problematic of this term, see Goldin 2011b.

3. Lüshi chunqiu, "Wuyi” 無義 22.2: 1491-1492; Shiji 68: 2237.

4. Shang Yang's cruel destiny - he was executed by the lord of the state which he loyally served for more than two decades - turned him into a tragic example of a selfless advisor being persecuted by the benighted ruler. For this view, and for appreciation of his success, see, e.g., Zhanguo ce, “Qin ce 秦策 1" 3.1: 71-72; “Qin ce 3” 5.18: 204-205; “Chu ce 
summary, that "from Han (206 BCE-220 CE) onwards scholars are ashamed of speaking about Shang Yang" is characteristic of the long-term attitude towards the Qin thinker. ${ }^{5}$

Shang Yang's image improved in the early 20th century, when several Chinese intellectuals, most notably Mai Menghua (1874-1915), rediscovered this thinker, and, impressed by perceived commonalities between his ideas and modern Western social thought, elevated him to the position of eminence which had been denied him for two odd millennia. While only a minority of modern scholars followed this view, in the latter years of Mao Zedong's era (1949-1976), Shang Yang's popularity soared, and he was lionized as a great "progressive" thinker who fought against the "reactionary classes." This enthusiasm remained brief though, and while in China nowadays Shang Yang is no longer demonized, the interest in his thought and legacy has subsided notably. ${ }^{6}$ In Western sinology, attitudes toward Shang Yang remain overwhelmingly negative; while some identify him as "totalitarian" thinker and representative of an "amoral science of statecraft," others tend to disregard him altogether, as is reflected in an almost unbelievable dearth of Western language publications that deal with Shang Yang. ${ }^{7}$

楚策 4” 17.13: 598; Han Feizi, “He shi” 和氏 IV.13: 275; “Jian, jie, shi chen” 姦劫弑 臣 IV.14: 283.

5. Su Shi, Dongpo quanji 105: 13-15 on p. 14; for more on attitudes toward Shang Yang, see $e . g$. Zeng Zhenyu 2003. Zhang Jue (2006) conveniently collects views of Shang Yang from the Warring States to the early Republican period. Su Shi's invective against Shang Yang might have been triggered by a rare example of positive assessment of Shang Yang's success, by Su Shi's arch-rival Wang Anshi (1021-1086) (for whose views of Shang Yang, see Yang Xiaoshan 2007: 77).

6. Views of Shang Yang from the turn of the 20th century to the age of the anti-Confucian campaign of the early 1970s are summarized by Li Yu-ning 1977; for a very brief summary of later research trends, see Zhao Yuzhuo 2010.

7. For labeling Shang Yang "totalitarian" thinker, see, e.g., Creel 1953: 135-158; Rubin 1976: 55-88; Fu Zhengyuan 1996; for his perceived amorality, see Graham 1989: 267292; for more balanced assessments, see Schwartz 1985: 330-335; Lewis 2007: 46-50. The lack of interest in Shang Yang is epitomized not only by his omission from some of the major studies of early Chinese philosophy (e.g. Nivison 1999), but mostly from a ridiculously small number of scholarly articles dedicated to this thinker. My querying the extensive Ancient Chinese Civilization: Bibliography of Materials in Western Languages by Paul R. Goldin (2011c) has yielded but three articles directly related to The Book of Lord Shang: Kandel 1985; Handelman 1995 and Boesche 2008; to this one should add Fischer 2012. Most recently, an issue on "Legalism" by the Journal of Chinese Philosophy 38.1 (2011) failed to dedicate a single article to Shang Yang or otherwise meaningfully to engage his thought (for an exception see Goldin 2011b). 
To be sure, criticism of Shang Yang's perceived immorality and the lack of interest in his intellectual legacy are two distinct phenomena; but they are related to a certain extent. One may identify several reasons for which "scholars are ashamed of speaking about Shang Yang," and among these the peculiar content of the Book of Lord Shang (Shang jun shu), ${ }^{8}$ attributed to Shang Yang, figures prominently. Few if any other pre-imperial texts contain such a blatant assault on conventional morality: deriding fundamental moral norms, such as benevolence, righteousness, filiality, fraternal duty, trustworthiness and honesty, as "parasites"; calling for the creation of a regime in which "scoundrels rule the good"; and advocating military victory by performing "whatever the enemy is ashamed of." Such examples of what may be called "alienating rhetoric" abound in the book, and they may have generated the negative view of Shang Yang among the majority of both traditional and modern readers.

In what follows I want first to analyze the "alienating rhetoric" of the Book of Lord Shang in terms of its content, its purported audience and its potential effect. Then I shall go a step deeper into the text and try to demonstrate that in the process of the evolution of the Book of Lord Shang, one can discern attempts by later contributors to moderate the negative impression left by the most blatantly alienating chapters, which, I believe, belong to the earlier layer of the text. I hope that by comparing the two sets of chapters, I shall be able to add yet another dimension to the ongoing discussion about the formation of the Book of Lord Shang and its ideological evolution, demonstrating thereby that analysis of the text's rhetoric may be a useful device in assessing its nature and its composition.

\section{Preface: the composition of the Book of Lord Shang}

Any analysis of the Book of Lord Shang should begin with the thorny question of its dating and composition. Although this text was not the focus of scholarly attention in traditional China, a few scholars who did address its nature noticed that it contains a few obviously anachronistic references to the events from the very end of the Warring States period (Zhanguo, 453-221 $\mathrm{BCE}$ ), which suggest that it was composed long after the death of its putative author, Shang Yang. This view, in turn, generated a dismissive attitude toward the Book of Lord Shang during the Republican period (1912-1949), when many eminent scholars presupposed its belatedness and consequently downplayed its ideological importance, making it secondary to the Han Feizi as a source of so-called "Legalist" thought. Although these sweeping generalizations are no

8. In citing The Book of Lord Shang, I abbreviate it as SJS. 
longer accepted in Chinese and Japanese research, they continue to influence not a few Western studies, which may explain yet another reason for the paucity of interest in the Book of Lord Shang in the Anglophone community. ${ }^{9}$

It is important to emphasize from the very beginning that the outdated reductionist view, which dates the text according to its latest identifiable layer, is untenable. A more convincing scenario would be akin to that outlined by Mark E. Lewis: namely, texts attributed to major thinkers were created as a result of a lengthy process of accretion, during which disciples and followers added, edited and possibly edited out chapters or sections of the text; hence rather than trying to date the text as a whole, we should focus on the provenance of its "building blocks": either individual chapters or sections of a chapter. ${ }^{10}$ This view is indeed adopted nowadays by the vast majority of the scholars of the Book of Lord Shang in China and Japan; and many efforts have been made to distinguish between those chapters that can be identified as Shang Yang's writings, those attributable to his immediate followers and disciples, and those produced at a later stage, or, possibly, mistakenly added to the book. The results of these efforts are both impressive and frustrating: impressive due to manifold new insights on the structure of the Book of Lord Shang; frustrating - because of the very considerable disagreement with regard to the dating of most of the chapters. Aside from chapter 2, "Ken ling" ("Order to cultivate wastelands"), which is overwhelmingly identified as produced by Shang Yang, and chapter 15, "Lai min" ("Attracting the people"), which was definitely produced after 260 BCE, the dating and authorship of other chapters remain bitterly contested. ${ }^{11}$ While in the present paper I do not intend to address these debates systematically, a few brief observations would clarify my approach and explain similarities and differences between my views and those of earlier researchers.

9. For the Republican period insistence on the belatedness of the Book of Lord Shang in its entirety, and its subsequent rejection as a source for Shang Yang's activities and thought see, e.g., Hu Shi 1919: 322-323; Liang Qichao 1922: 80; Luo Genze 1935; Qian Mu 1935: 266-267; Guo Moruo 1945: 236; Qi Sihe 1947; for this analysis echoed in a major Western study, see Graham 1989: 267-292. Nivison's (1999) refusal to address Shang Yang's thought may also be related to this trend. In contrast to a somewhat cavalier approach adopted in many of these studies, Duyvendak (1928: 75-87) made an earnest, even if nowadays somewhat outdated, attempt to distinguish different temporal layers in the Book of Lord Shang.

10. Lewis 1999: 58; $c f$. Boltz 2005. For an alternative view of the "accretion" theory, see Brooks and Brooks 1998.

11. For major studies of the dating and the composition of the Book of Lord Shang, see Zheng Liangshu 1989; Yoshinami 1992; Zhang Jue 2006; Tong Weimin 2007; Zhang Linxiang 2008. 
Two major problems characterize the majority of studies of the composition of the Book of Lord Shang. First, scholars routinely employ the "Biography of Lord Shang" in the Historical Records as the source of reliable information on Shang Yang's life and thought; accordingly the attribution of individual chapters is contested according to the degree of its conformity with the image of Shang Yang as perceived from that text. This a-priori prioritization of a source that was definitely composed long after the Book of Lord Shang, and that is obviously not free of manifold bias, is methodologically untenable. ${ }^{12}$ Second, scholars often expect that chapters composed by Shang Yang should display absolute ideological uniformity. This expectation is likewise problematic: a thinker and a statesman, whose career in Qin spanned two decades, can be expected to modify his views either due to changing circumstances, or due to differences in the expected audience of individual chapters. Actually, few texts of the Warring States period display such a remarkable degree of ideological consistency as the Book of Lord Shang; but when differences do occur-such as regarding the proper balance between rewards and punishments - they cannot serve as a reliable indicator of the chapter's provenance, as has been suggested, for instance, by Zheng Liangshu (1989). We should look for more solid criteria in dating individual chapters of the Book of Lord Shang, either in absolute or in relative terms.

These solid criteria do exist, at least with regard to a few chapters. Most obviously, references to the events that postdate Shang Yang's death by years or even by generations are indicative of the belated creation of several chapters, e.g. of "Attracting the people," noted above. ${ }^{13}$ Another indicator for the chapter dating are the ruler's appellations. While most chapters apply the neutral "ruler" (jun) and "sovereign" (zhu), a few others employ "king" (wang), which suggests that they were produced after the appropriation of the royal title by Lord (later King) Huiwen of Qin (r. 337-311) in 325 BCE; ${ }^{14}$ another chapter (26, "Ding fen," "Fixing distinctions") speaks of the ruler as "Son of Heaven" (Tianzi) which suggests a provenance around the age of the imperial unification of $221 \mathrm{BCE}$.

12. For problems of Shang Yang's biography in the Shiji, see Yoshimoto 2000.

13. Two other chapters with obvious anachronisms are "Establishing laws" (9, "Cuo fa") and "Weakening the people" (20, "Ruo min"), although in both cases a passage with anachronistic data might have been inadvertently added to the chapter by later transmitters.

14. These are, e.g., chapters "Rewards and punishments" (17, "Shang xing"), "Within the borders" (19, "Jing nei"), and, again, "Attracting the people." Even if these chapters were produced in other Warring States, whose rulers adopted the royal title earlier than in Qin, they definitely do not belong to the earliest layer of the Book of Lord Shang. 
Variations in the ruler's appellations bring us to another interesting difference among the chapters of the Book of Lord Shang: their preoccupation with the concept of the True Monarch. As I have argued elsewhere, from the Middle Warring States period onwards, many texts focus on this figure of an ideal ruler, who will be able to unify All under Heaven under his aegis and bring universal peace and stability. ${ }^{15}$ The Book of Lord Shang is one of the earliest texts in which this topic figures prominently; yet the intensity of discussion differs considerably among various chapters. Some chapters, most notably 3, "Nong zhan" ("Agriculture and warfare") and 4, "Qu qiang" ("Eliminating the strong"), as well as those related to "Qu qiang" (see below), abound with promises for a ruler who heeds the authors' advice to become the True Monarch; in others, including all the identifiably late chapters, these pronouncements disappear. It is likely that the difference again revolves around 325 BCE: after the Qin rulers adopted the king/monarch (wang) title it was no longer politically advisable to emphasize the ruler's need to become True Monarch, implying thereby that his current title is fraudulent. This in turn suggests that chapters 3 and 4 (and a few others, such as "Opening the barred" [7, "Kai sai”]) may well belong to an earlier layer of the Book of Lord Shang. If correct, this observation is singularly important for the discussion below, as it is precisely in chapters 3 and 4 that an assault on traditional moral values appears particularly blatant.

One final point should be made here with regard to chapter 4 ("Eliminating the strong"). In all likelihood it occupies a special position within the Book of Lord Shang. As has been noticed by several scholars, two other chapters of the book (5, "Shuo min," "Explaining the people"; and 20, "Ruo min," "Weakening the people") are commentaries on the "Eliminating the strong" chapter. ${ }^{16}$ In addition, one more chapter (13, "Jin ling," "Making orders strict," reproduced as "Chi ling" in the Han Feizi) appears to be closely related to "Eliminating the strong." While the dating of each chapter in this cluster is debatable (see more below), it is highly likely that the "Eliminating the strong" chapter precedes the three others, and that it might have been conceived of as a kind of "canon" to which commentaries were added at a later stage. This hypothesis, if correct, strengthens my observation with regard to the relatively early date of the "Eliminating the strong" chapter, and will serve us later when we address the

15. The concept of the True Monarch is distinguished from that of a regular "king" by the usage of the term wang in its verbal meaning ("to act as a [true] monarch"), by the compound wang zhe, by the notion of the Monarch's Way (Wang Dao) and the like (see Pines 2009: 229, n. 5). In the Book of Lord Shang, the verbal usage of the term wang prevails.

16. See discussions by Jiang Lihong in Shang jun shu: 152-162; and Zheng Liangshu 1989: 269-277. 
modification of the message of that chapter in the "inner commentary" of the Book of Lord Shang.

My discussion below will start with analyzing "alienating rhetoric" in chapters 3 and 4 of the Book of Lord Shang; in the next section I shall move to those chapters which in all likelihood come from the later layers of the book, and show how the alienating rhetoric underwent modification and moderation so as to make the text more accommodative toward potential opponents.

\section{Down with morality! The earliest layer of the Book of Lord Shang}

Chapter 3, "Agriculture and warfare" is one of the central ideological pieces in the Book of Lord Shang. Its focus is clear from the title: the author proposes various means for directing the population towards the mutually reinforcing pursuits of agriculture and warfare-combined under the name "the One" (yi) - as this is the only way the state will become powerful domestically and externally. To attain this goal, it is essential to undermine the attractiveness of alternative occupations, such as commerce, craftsmanship, and, most importantly, intellectual pursuits. The author is particularly critical of traveling scholars and of the so-called "powerful and eminent" (hao jie) who "change their occupation, diligently study Poems and Documents and then follow external powers to attain renown above and offices and emoluments below." ${ }^{17}$ These crafty and talkative intellectuals are the major malady of the state: "When one thousand people are engaged in agriculture and war, yet there is a single man among them engaged in Poems, Documents, argumentativeness and cleverness, then one thousand people all will become remiss in agriculture and war." ${ }^{18}$ Moreover, attraction to scholarly pursuits damages the functioning of the government above: "the ruler is fond of words, while officials lose the constant"; ${ }^{19}$ thereby the state is led astray from the Way of the Monarch.

The author's assault on intellectuals matures at the middle of the chapter, where their negative impact on the state is summarized:

17. 是故豪傑皆可變業, 務學詩書, 隨從外權, 上可以得顯, 下可以得官爵 $(S J S$, “Nong zhan" I.3: 22). "External powers" evidently refers to foreign states, which often meddled in the domestic affairs of their rivals by fostering ties with powerful statesmen.

18. 農戰之民千人, 而有詩書辯慧者一人焉, 千人者皆急於農 戰矣。SJS, “Nong zhan” I.3: 22 .

19.上好言而官失常也。SJS, “Nong zhan” I.3: 22. “The constant” (常) here and elsewhere in the Book of Lord Shang refers to the essentials of the Law (see e.g. SJS, IV.18: 113). 


\section{Yuri Pines}

Now, when superiors employ the people only after discussing their talents, abilities, knowledge and cleverness, then the knowledgeable and the clever will observe ${ }^{20}$ the ruler's likes and dislikes and let the officials manage the affairs so as to conform to the sovereign's heart. Therefore, the officials will lack the constant, the state will be in turmoil and not engaged in the One, while argumentative persuaders will not [be reined in by] the Law. In this case, how can the people's pursuits be not multiple; how can the land be not waste? ${ }^{21}$

Having identified "the knowledgeable and the clever" intellectuals as the most hazardous social stratum, the author launches a massive assault on traditional culture and morality as a whole:

Poems, Documents, rites, music, goodness, self-cultivation, benevolence, uprightness, argumentativeness, cleverness: when the state has these ten, the superiors cannot force the people to [engage in] defense and warfare. If the state is ruled according to these ten, then when the enemy arrives it will be dismembered, and when the enemy does not arrive, it will be impoverished. If the state eradicates these ten, then the enemy will dare not to arrive, and even if he arrives, he will be repelled; when the army is raised and sent on a campaign it will seize [the enemy's land]; while if the army is restrained and does not attack, the state will be rich. ${ }^{22}$

This passage - which, as we shall see recurs with minor variations elsewhere in the text-epitomizes the author's disdain not only of traditional culture as represented by Poems, Documents, rites and music, but of traditional moral values as well. At first glance his dislike of "goodness, self-cultivation, benevolence and uprightness" is almost inexplicable; these values are not mentioned elsewhere in the chapter. What then is the damage from these values? An implicit answer will be that the author does not assault morality as such but is critical of moralizing discourse, due to which "the ruler is muddled by the doctrines, the officials are disordered by discourses, and the people are indolent in agriculture." ${ }^{23}$ Yet if this is indeed the author's intention (and I very much believe it is), it is never made explicit in the chapter. A reader-both traditional and modern-is left with a bad taste of a manifestly immoral text, which does not care about attracting the reader but rather openly alienates him.

20. Following Gao Heng 1974: 36, n. 29, I emend 希 to 晞.

21. 今上論材能知慧而任之, 則知慧之人希 (晞) 主好惡, 使官制物, 以適主心。是 以官無常, 國亂而不壹, 辯說之人而無法也。如此, 則民務焉得無多, 而地焉 得無荒? SJS, “Nong zhan” I.3: 22-23.

22. 詩、書、禮、樂、善、修、仁、廉、辡、慧, 國有十者, 上無使守戰。國以十 者治, 敵至必削, 不至必貧。國去此十者, 敵不敢至; 雖至, 必卻; 興兵而伐, 必取;按兵不伐, 必富。SJS, “Nong zhan” I.3: 23 .

23. 是以其君惛於說, 其官亂於言, 其民惰而不農. SJS, “Nong zhan” I.3: 23. 
The reader's feeling of alienation increases dramatically in the next chapter, "Eliminating the strong." Unlike the preceding chapter, "Eliminating the strong" does not focus on a single topic, but rather presents a series of brief statements that purport to be the quintessence of Shang Yang's wisdom. The chapter's eclectic nature has led some scholars to assume that it was produced later than the bulk of the text, as a sort of intellectual summary of Shang Yang's legacy. ${ }^{24}$ This supposition, however, is not convincing: the fact that "Eliminating the strong" is the only chapter of the Book of Lord Shang to merit addition of two exegetical chapters makes it highly likely that from the inception it was conceived as a pivot of the book's message, a "canon" to be followed by "commentaries." In that case the message in "Eliminating the strong" and even its wording should be of utmost interest to scholars of Shang Yang's thought.

The chapter's peculiar message becomes clear from its first lines:

One who eliminates the strong with the strong is weak; one who eliminates the strong with the weak is strong. When the state engages in goodness, there are many scoundrels. When a rich state is ruled as poor, it is called multiplying riches; he who multiplies riches is strong. When a poor state is ruled as rich, it is called multiplying poverty; he who multiplies poverty is weak. He whose army performs whatever the enemy dares not to perform, is strong; he, who in [military] affairs elevates whatever the enemy is ashamed of, benefits. ${ }^{25}$

Some of the above statements, especially the first sentence, are enigmatic and require exegesis in the "Weakening the people" chapter to be adequately understood, ${ }^{26}$ yet other phrases are clear enough. Of these, two leave the reader most uncomfortable: the statement "when the state engages in goodness, there are many scoundrels," and the recommendation for the army "to perform whatever the enemy is ashamed of." The latter recommendation might have given rise to stories of Shang Yang's dirty tricks on the battlefield, as narrated

24. See discussions in Zheng Liangshu 1989: 23-30; Zhang Linxiang 2008: 101-104.

25. 以彊去彊者, 弱; 以弱去䮠者, 彊。國為善, 姦必多。國富而貧治, 曰重富, 重富 者彊。國貧而富治, 曰重貧, 重貧者弱。兵行敵所不敢行, 彊; 事興敵所差為, 利。SJS, “Qu qiang” I.4: 27.

26. The "Weakening the people" chapter explains that "strong" and "weak" refer to the fundamental principle of "weakening the people to strengthen the state"; yet possible textual corruption in the first lines of the "Weakening the people" chapter causes considerable confusion as to what should be understood as "eliminating the strong with the strong" (see SJS V.20: 121-122). In distinction from most commentators, I believe that the passage cautions against the policy of weakening the people through over-empowerment of the state apparatus; yet I shall leave a detailed discussion of this topic to another occasion. 


\section{Yuri Pines}

in Lüshi chunqiu, among others; ${ }^{27}$ and as we shall see later, they required the considerable intellectual acrobatics of the text's exegetes to make them sound less alienating. In the "Eliminating the strong" chapter itself, this phrase is left without further elaboration; rather the author continues to engage in provocative and unconventional statements:

Peasants, merchants and officials: these three are constant functions of the state. Three functions give birth to six parasitic affairs, ${ }^{28}$ that is "year," "food," "beauty," "likes," "will," "conduct." When the six have the root, ${ }^{29}$ [the state] will surely be dismembered. The root of three functions in three kinds of the people; the root of six [parasitic] affairs is in one Man... When a powerful state is not engaged in warfare, the poison infiltrates its intestines; rites, music and parasitic affairs are born; [the state] will surely be dismembered. When the state wages war, the poison infiltrates the enemy; it lacks rites, music and parasitic affairs; [the state] will surely be strong. ${ }^{30}$

The six parasitic affairs assaulted here are rarely if at all singled out as negative phenomena; according to the exegesis in the "Weakening the people" chapter, they refer to the peasant's extravagant feasting in the case of an abundant yearly harvest, to the extra incomes of the merchants from beautiful utensils, and to officials' engagement with self-cultivation at the expense of performing their duties. Without an exegesis, which clarifies that the chapter hints at selfindulgent excesses, the statement sounds odd and may further alienate the audience. The alienation increases when we read the author's argumentation in favor of war: rather than focusing on its contribution to the state's security and prosperity, he singles out its cultural impact on eliminating "rites and music" along with other parasitic affairs. This argument, again, sounds odd: instead of looking for common ground with his potential opponents, the author appears to be delighted to create more controversies. This delight is even more evident in the next section:

When the state has rites and music, Odes and Documents, goodness and selfcultivation, filiality and fraternal obligations, uprightness and argumentativenesswhen it has all ten of these, the superiors cannot cause [the people] to go to war, and [the state] will surely be dismembered to the point of final collapse; when the state lacks all ten of these, the superiors can cause [the people] to go to war, and [the

27. Lüshi chunqiu, “Wuyi” 無義 22.2: 1491-1492.

28. Following Zhang Jue 2006: 38, I read 官 in 强官 as synonymous with 事.

29. Following Gao Heng 1974: 223, I read 樸 as “root."

30. 農、商、官三者, 國之常官也。三官者生䖵官者六: 歲, 曰食, 曰美, 曰好, 曰 志, 曰行。六者有樸, 必削。三官之樸三人, 六官之樸一人。...國彊而不戰, 毒 輸於內, 禮樂革官生, 必削; 國遂戰, 毒輸於敵國, 無禮樂䖵官, 必䮠。SJS, “Qu qiang" I.4: 28 . 
state] will surely prosper to the point of [its ruler] becoming True Monarch. When the state employs the good people to rule scoundrels, it will suffer chaos to the point of dismemberment; when the state employs scoundrels to rule the good people, it will be orderly ruled to the point of empowerment. When the state uses Odes, Documents, rites, music, filiality, fraternal obligations, goodness and argumentativeness to rule, then when the enemy arrives the state will be dismembered; and when the enemy does not arrive, it will be impoverished. When one does not use these eight, then the enemy dares not arrive; and even if he arrives, he will be repelled; while when the army is raised in invasion it will be able to seize [the enemy's territory], and after seizing it, will surely be able to hold it; while when one restrains the army and does not attack, [the state] will surely be rich. ${ }^{31}$

This section echoes the previous chapter in its assault on the entire spectrum of cultural and moral values of the author's contemporaries. The list of vices is similar to that in "Agriculture and warfare," but there is one important addition: that of filiality and fraternal obligations. This addition is not negligible: of all major virtues, filiality might have been the least controversial, and by vigorously assaulting it, the author could not but arouse further animosity in most readers. ${ }^{32}$ Once again, the author does not explain why specific virtues were singled out for his disdain; rather it seems that he has created an inversion of several "Confucian" texts in which positive virtues were put together to urge the rulers to adopt them in toto; ${ }^{33}$ in his case, he simply advocates total rejection. This "totalistic iconoclasm," to echo Lin Yü-sheng, ${ }^{34}$ is still not enough for the author in his search for appalling statements; hence he crowns his crusade

31. 國有禮有樂, 有詩有書, 有善有修, 有孝有弟, 有廉有辯一一國有十者, 上無使 戰, 必削至亡;國無十者, 上有使戰, 必興至王。國以善民治姦民者, 必亂至削; 國以姦民治善民者, 必治至彊。國用詩書禮樂孝弟善修治者, 敵至必削國, 不至 必貧國。不用八者治, 敵不敢至, 雖至, 必卻;興兵而伐, 必取, 取必能有之;按 兵而不攻, 必富。SJS, “Qu qiang” I.4: 29-30.

32. Chen Li 陳澧 (1810-1882) noticed: “One should not talk about rites, music, Odes, Documents, benevolence and righteousness; but as for filiality and fraternal duties: they were adored by everyone since the beginning of humankind; yet Shang Yang considers them parasites that will [lead the state] to sure dismemberment and collapse. One who is neither owl nor leopard (two supposedly parent-devouring animals) but still says these words...: even being dismembered by the chariots is not enough to erase his crime!" Dong shu dushu ji 12: 247.

33. See, e.g., Guоyu, “Zhou yu 1" 周語上 1.14: 36-37; “Zhou yu 3” 周語下 3.2: 88-89; cf. the Wu xing text from Guodian (Li Ling 2002: 78-80) and from Mawangdui, and the like.

34. Lin Yü-sheng 1979. 
against morality with the oddest recommendation to let "scoundrels rule the good people." 35 The entire moral order is turned upside down.

\section{Why abuse the audience? The rationale behind the alienating rhetoric}

The above analysis leaves no doubt that both chapters 3 and 4 were designed to appall and alienate the audience. Their alienating impact becomes even clearer when we compare them to a few other contemporaneous texts which likewise assaulted aspects of traditional culture and cherished moral values. In terms of content, pronouncements in these texts might have been no less controversial than those in the Book of Lord Shang: suffice it to mention Mozi's ( ca 460-390 $\mathrm{BCE}$ ) assault on lavish funerals and ritual music; the Laozi dictum "Cut off benevolence, abandon righteousness, and the people will return to filiality and paternal love"; and some of the Zhuangzi statements, e.g. "until the sages die out, criminals could not be stopped." ${ }^{36}$ Later, Han Feizi (d. 233 BCE) echoed Shang Yang's derision of fundamental political and ethical beliefs of the elite. Yet similarities aside, I believe that the impact of these texts on the audience was fundamentally different from that of the Book of Lord Shang, and the difference was less related to the content and more to the form of the argument.

Let us briefly consider how the texts mentioned above convey their message. Mozi is anxious to convince his audience that, first, his controversial ideas reflect the true legacy of the sage kings of antiquity, and, second, that they are obviously beneficent to the socioeconomic wellbeing of the populace. The case of the Laozi is more complicated; surely, for many readers the call to "cut off benevolence and abandon righteousness" was no less provocative than Shang Yang's statements cited above. Nonetheless, the alienating effect of the Laozi statements is moderated in several ways. First, the text's promise that after heeding its advice the people would return to "filiality and paternal love" means that, in sharp distinction from the Book of Lord Shang, the Laozi accepts at least

35. It should be noticed that the term jian 姦 (which I translate as "scoundrels") belongs to one of the most negative designations in Chinese political discourse; I am not aware of a single other text which employs this term in a positive way.

36. See Mozi, “Jie zang xia” 節葬下 VI.25: 262-268; “Fei yue shang” 非樂上 VIII.32: 379-383; Laozi's “When the Great Way declines, 'benevolence' and 'righteousness' appear” (大道廢焉, 有仁義) and the above citation (絕仁棄義, 民復孝慈) Boshu Laozi 18-19: 310-312 (but notice that in the Guodian [proto-]Laozi text, the second of these phrases replaces "benevolence and righteousness" with much less controversial “knowledge and argumentation” [絕智棄辯, Guodian Laozi A, slip 1 cited from Li Ling 2002: 4]); and Zhuangzi”s 聖人不死, 大盗不止 (Zhuangzi “Qu qie”胠筴 10: 256). 
some of the moral values cherished by the members of the elite. ${ }^{37}$ Second, the Laozi provocative arguments can be understood in the context of manifold paradoxical statements in the text, which allows reading the above dictum as an attack on erroneous terminology rather than on moral values as such: it opposes the much trumpeted terms rather than the real ethical norms that stand behind these terms..$^{38}$ Third, and most importantly, the Laozi clarifies elsewhere the reasons for its dismissive attitude toward "benevolence and righteousness": these are just artificial values which appear in the wake of the decline of the pristine Way and Virtue ${ }^{39}$ Evidently, the text does not oppose morality as such but just its man-made definitions. Overall, the Laozi establishes a sort of dialogue with its readers and does not just astound them with an attack on their cherished beliefs; this distinguishes the text critically from the above chapters of the Book of Lord Shang. As for the Zhuangzi, there the author's irony softens much of the text's messages.

Now, what about Han Feizi? This text shares much of the worldview, argumentation and vocabulary with the Book of Lord Shang and is particularly fitting for comparative purposes. Quite often Han Feizi sounds no less provocative than Shang Yang; and yet the assault on traditional values in the Han Feizi in the final account appears much less vehement than in chapters 3 and 4 of the Book of Lord Shang. Thus, in the Han Feizi filial piety is not rejected in toto but is juxtaposed with another highly acclaimed value - namely, loyalty to the ruler-and is shown to be detrimental to the latter; nor does the text discard benevolence altogether, but rather shows its inadequacy under the current sociopolitical conditions. ${ }^{40}$ Surely, many readers would remain alienated from Han Feizi's message, but at the very least the author-much like the authors of the later chapters in the Book of Lord Shang, discussed below - tries to establish a common ground with the reader rather than abuse him.

Going back to chapters 3 and 4 of the Book of Lord Shang discussed above, we may immediately notice how different they are from other "provocative" texts. First, Shang Yang's iconoclasm in the cited chapters is totalistic rather than

37. For the Laozi's promise to bring about filiality and paternal love, see Boshu Laozi 19: 312; for more on the Laozi's complex approach toward filiality, see, e.g., Ikeda 2004.

38. For multiple paradoxes in the text, which teach the reader to mistrust external appearances and common definitions, see, e.g., Boshu Laozi 41: 21-24; 45: 41-44.

39. See Boshu Laozi 38: 1-5. I cannot adequately address here the complex issue of the dating of individual sections of the Laozi and avoid what may become a speculative discussion about how the messages of that text could have been modified in the process of its formation and early transmission.

40. Han Feizi, “Wu du” 五蛽 XIX.49: 1109 and 1092-1093. Notably, elsewhere Han Feizi embraces filiality as a positive moral value (e.g. “Zhong xiao”忠孝 XXI.51: 1151). 
selective, as in the Mozi or the Laozi. Second, it is presented in an absolutely straightforward way, not mediated either by appealing to the Way of the former kings, as in the Mozi, or by metaphysical depth, as in the Laozi. Third, unlike another iconoclastic text, the Zhuangzi, Shang Yang's invectives against morality cannot be reduced to literary exercises or ironic digressions; rather, they appear as a call for action, which may well be frightening for some of the audience. And finally, "immoral" pronouncements are neither explained nor justified; unlike the Han Feizi (or later chapters in the Book of Lord Shang itself), they are presented as unquestionable axioms; the author does not try to engage his readers in dialogue. Rather, the audience is left with a choice of "take it or leave it," and the majority would doubtlessly opt for the latter. Only once does the "Eliminating the strong" chapter sound more accommodating:

When one eradicates punishments through punishments, the state is ordered; when one brings punishments through punishments, the state is disordered. Hence, it is said: when in implementing punishments you [punish] heavily for light [offenses], the punishments are eradicated, the affairs are completed and the state is strong; when you punish heavily for heavy [offenses] and lightly for light ones, the punishments are brought in, [more] affairs are born, and the state is dismembered. Punishments give birth to power; power gives birth to strength; strength gives birth to awesomeness; awesomeness gives birth to kindness: kindness is borne of power. ${ }^{41}$

The concluding sentence is indicative of the sophistication of the argumentation in the Book of Lord Shang; as we shall see, in most other chapters, the authors justify the harshness of their proposals by explaining the ultimately blessed impact of these on the populace. In the context of the given chapter, however, a single sentence does not alleviate the harsh feelings engendered in the reader by a series of explicitly immoral pronouncements. It seems that rather than placating the audience, the author of this (and the previous) chapter is satisfied by further irritating it.

A reader may well question at this point why, if at all, I apply the term "rhetoric" to the way in which the Book of Lord Shang presents its harsh message. After all, "rhetoric" is commonly understood as being aimed at persuading the audience, not alienating it. Can we apply this term to the overtly abusive messages of the two chapters discussed above? I believe we can: in our case harsh statements may well be a calculated gamble: while alienating most of the educated elite, the author was subtly targeting a significant segment thereof.

41. 以刑去刑, 國治;以刑致刑, 國亂。故曰:行刑重輕, 刑去事成, 國彊; 重重而輕 輕, 刑至事生, 國削。刑生力, 力生彊, 彊生威, 威生惠, 惠生於力。SJS, “Qu qiang" I.4: 32 . 
As such, his controversial pronouncements may well be an efficient rhetorical device.

Let us assess now whom did the author target: who was the expected audience of both chapters? A ready answer would be that the texts were prepared by Shang Yang for his employer, Lord Xiao of Qin (r. 361-338), and were formulated in such a way as to please the lord. This suggestion would fit nicely with an anecdote told in the Historical Records, according to which Shang Yang tried at first to teach Lord Xiao the ways of Thearch and Monarch, and only after having failed in this, turned to "the way of hegemon," namely promoting an efficient, even if immoral rule. ${ }^{42} \mathrm{~A}$ second, related explanation would focus not on Lord Xiao's individual qualities but rather on the cultural background of Qin leaders. Namely, the state of Qin was supposedly a "barbarous outsider" of the Zhou world, which was therefore more receptive to Shang Yang's anti-cultural messages. This explanation is traceable already to the Huainanzi, which argues that Shang Yang's laws were constructed so as to fit original Qin customs that were "covetous and wolfish, forceful and violent." 43 In the 20th century many modern scholars, such as Meng Wentong (1894-1968) and others, have put forward a theory that Qin was originally an alien (Rong) polity, which did not share the common cultural values of the Zhou world; this supposition in turn explains why an assault on Tradition, which might have been unthinkable elsewhere in the Zhou oikoumenē, was acceptable in Qin. ${ }^{44}$

Let us start with the second, cultural explanation of Shang Yang's peculiar rhetoric. Convenient as it may seem, this explanation is patently wrong. It is clear nowadays that the association of Qin with the cultural Other of the Zhou world is built on an uncritical acceptance of political propaganda of the late Warring States period, rather than on cultural realities. A careful investigation of textual, archeological and paleographic data shows beyond doubt that from the earliest identifiable stages of its history, Qin was a part of the Zhou cultural sphere, and its differentiation from the rest of the Central States occurred in the aftermath of Shang Yang's reforms, rather than prior to these reforms.$^{45} \mathrm{In}$ cultural terms, therefore, the rhetoric of the Book of Lord Shang would have been as alienating for the Qin audience as it might have been elsewhere in the Zhou oikoumenē.

42. Shiji 68: 2228.

43. Translation cited from Major et al. 2010: 21, 866-867.

44. Meng Wentong 1936; for elaboration of this view, see, e.g., Liu Yutao 1988; Liu Chunhua 2005. Zheng Liangshu (1989) also shares this estimate of the Qin cultural background, using it for his analysis of the composition of the Book of Lord Shang.

45. See Shelach and Pines 2005; Pines 2005/6; and collected articles in Pines et al. forthcoming; see also Kern 2000. 
Setting cultural explanations aside, let us check the feasibility of the first supposition, namely that the cited chapters were prepared exclusively for Lord Xiao of Qin, whose individual predilections might have turned him into an eager consumer of Shang Yang's arguments. Without entering speculative discussion about Lord Xiao's ideological inclinations, it is important to observe that neither of the two chapters discussed above appear as being directed exclusively at the lord. First, the wording of both chapters lacks any hint of personal communication with the ruler, unlike in the case of many other chapters in the Book of Lord Shang. ${ }^{46}$ Second, whoever their original addressee, once these chapters were incorporated in the collection of Shang Yang's alleged writings, it was clear that they would be read by much broader audience than a ruler and his close aides. The very fact that the "Eliminating the strong" chapter was provided with extended exegesis suggests that at a certain point it began circulating widely enough to require written commentaries. Hence, I believe that both chapters analyzed above were targeting not just the ruler but a broader segment of the educated elite.

If my conclusion is correct, then why did the author adopt his radically alienating rhetoric? What did he hope to achieve by assaulting values and norms that had clearly pronounced "emotive meaning" for the majority of the readers? ${ }^{47}$ To answer this question, we should consider the peculiar intellectual atmosphere of the middle Warring States period. It was an age of profound socio-political, economic and military changes; the age when old values were reexamined and no strict orthodoxy existed. In these conditions an assault on dominant values, couched in provocative and even abusive language, was surely alienating for many, but could also increase the author's renown, and possibly his attractiveness among those segments of the educated elite who would share his radical rejection of mainstream views. The language of these chapters with its undeniable novelty and freedom from ideological conventions might have appealed to some; and it was positioning the supposed author of the Book of Lord Shang, Shang Yang, as a true leader of innovative thinkers. ${ }^{48}$

The intellectual history of the world, especially modern intellectual history, has several examples of a radical movement adopting abusive and alienating discourse to emphasize its novelty and to attract followers from the margins of

46. No less than seven chapters of the Book of Lord Shang contain the first person pronoun chen 臣, indicating that they originated from memorials submitted by Shang Yang and his followers to the lords of Qin (Gao Heng 1974: 8-9).

47. The concept of "emotive meaning" of ethical terms was developed by Stevenson (1938) and introduced into Sinology by Carine Defoort (2003).

48. I believe that this line of analysis may be applicable also to the Laozi and Zhuangzi, but this topic should be explored in a separate study. 
the establishment. Suffice to recall one example from modern Chinese history: the amazing popularity of "The Revolutionary Army" (Geming jun) by Zou Rong (1885-1905). Published in 1903, this short pamphlet became exceptionally successful: despite being banned, it sold an unimaginable one million copies, becoming one of the major bestsellers of the late Imperial period. ${ }^{49}$ The pamphlet attracted readers not due to intellectual depth - which it lacks - but because of its provocative language, full of racial abuse against the Manchu (Manju) rulers and against the imperial system. In the pre-revolutionary situation of the first decade of the 20th century, the inflammatory rhetoric of Zou Rong was precisely the kind of new discourse which many young literati (and even some of the established figures, such as Zhang Binglin [1868-1936]) were looking for. ${ }^{50}$

To be sure, the Zhou world in the fourth century BCE differed markedly from early modern China, and Shang Yang was not a young revolutionary but a powerful statesman; however there are some important similarities. Both societies were undergoing rapid changes, which invalidated some established beliefs and values; both were in search of novel solutions for a variety of socio-political challenges; both were characterized by a remarkable degree of intellectual pluralism, bolstered by the weaknesses of centralized political power. And, while Shang Yang was not a marginal player, unlike Zou Rong, he might have belonged to a distinct minority of intellectual radicals; hence, by emphasizing his divorce from Tradition he may have hoped to gain support within this minority.

We know next to nothing of Shang Yang's disciples, ${ }^{51}$ or of his attempts to establish a coherent group of followers; but there is at least one indication that such a group did exist. The Book of Lord Shang, the composition of which spanned several generations, was evidently the result of a collective effort. We do not know-despite the impressive efforts of scholars such as Zheng Liangshu and Yoshinami Takashi-how the book was formed and developed, nor the functioning of what Zheng dubs as Shang Yang's "ideological current" (xиe pai), but it is highly likely that the book was produced by a more or less ideologically coherent group of the thinker's followers, some of whom might have assisted Shang Yang in launching reforms in Qin. Plausibly, Shang Yang's followers were attracted precisely by those features of his thought, such as his

49. Schiffrin 1968: 273-274.

50. For the context of Zhang Binglin's involvement in revolutionary activities, see, e.g., Shimada 1990: 1-84.

51. The only preserved name of an alleged disciple of Shang Yang is that of Shi Jiao 尸佼, supposed author of the Shizi 尸子; yet his writings were classified by Ban Gu (班固, 32-92 CE) as belonging to a “miscellaneous school" ( $z$ a jia 雜家) and not to "Legalist" texts (Han shu 30: 1741). For aspects of the ideology of the Shizi, see Defoort 2001. 
blatant assault on established conventions, which were most controversial for other contemporaries and for posterity. If so, then Shang Yang's abusive rhetoric might have achieved its short-term goal, establishing the thinker's renown as the symbol of resolute innovativeness.

\section{Toward moderation: accommodating morality in the Book of Lord Shang}

If my parallel between Shang Yang and political radicals elsewhere is relevant, then we may expect a similar development trajectory: namely, after a group or an individual establish their credentials for radicalism and innovativeness, they begin moving back to the "political center," trying to establish bridges with the mainstream, rather than continuously alienating it. This trajectory is observable, e.g., in modern European history, where radicals on the right and on the left found it expedient at a certain stage to embrace, however superficially, the mainstream discourse of democracy and human rights, rather than trying to develop a comprehensively alternative vision. As I shall try to demonstrate below, this observation is correct with regard to Shang Yang (or, more likely, with regard to his ideological "current," whose members contributed to the evolution of the Book of Lord Shang). In many later chapters of this book, we can see a subtle but palpable change in the dominant rhetoric, from abusive to more accommodative.

I shall start my analysis in this section with three chapters that are clearly related to "Eliminating the strong," which, as noted above, epitomizes the overtly "immoral" message of the Book of Lord Shang. The task of explaining - and moderating - this message is performed in two exegetical chapters, each of which comments on approximately one half of "Eliminating the strong." The dating of both of these chapters - "Explaining the people" and "Weakening the people" - is not clear; although the last section of the latter contains a passage which must have been produced after $278 \mathrm{BCE}$, this passage is not related to the chapter and might have been mistakenly added by later transmitters ${ }^{52}$ It is possible that both were already produced during Shang Yang's life-time; but it is more likely that they were composed at a later stage, when the thinker's followers and disciples had to explain his terse and harsh message to a new audience. Whatever the answer, it is clear that both chapters reflect the evolution of Shang Yang's thought (or the thought of his followers).

How do the authors of the exegeses explain some of the harshest pronouncements in the "Eliminating the strong" chapter? The "Explaining the

52. See, e.g., Zheng Liangshu 1989: 44-46; Zhang Jue 2006: 157. 
people" chapter starts with a justification of the assault on moral and cultural values:

Argumentativeness and cleverness are the aides of turmoil; rites and music are symptoms of excessiveness and indolence; kindness and benevolence are mother of transgressions; appointing according to reputation ${ }^{53}$ is the rat ${ }^{54}$ of villainy. When turmoil has aides, it is realized; when excessiveness and indolence have symptoms, they are practiced; when transgressions have mother, they are born; when villainy has a rat, it cannot be stopped. When the eight come together, the people overcome the government; when there are none of the eight, the government overcomes the people. When the people overcome the government, the state is weak; when the government overcomes the people, the army is powerful. Hence, when the state has the eight of these, the superiors cannot cause the people to defend and fight, and it will surely be dismembered to the point of collapse; when the state has none of the eight, the superiors can cause the people to put up a defense and fight, and the state will prosper to the point of [its ruler] becoming [True] Monarch. ${ }^{55}$

These pronouncements, harsh as they are, differ in two critical ways from the mother passage in the "Eliminating the strong" chapter. First, the list of vices is modified: the most controversial pair of filiality and fraternal duties is replaced with much less controversial "appointing according to reputation." Second, the negative impact of each of the vices is explained; and while many readers may remain unconvinced by these explanations, they do at the very least propose a common ground for debate-advantages and disadvantages of empowering the people vis-à-vis the state-rather than merely alienating the audience. This softening effect of explanations of Shang Yang's maxims is even clearer in the next section:

When the good are employed, the people are attached to their relatives; when scoundrels are employed, the people are attached to regulations. Those who are harmonious and cover ${ }^{56}$ each other are "good"; those who are separate and regulate each other are "scoundrels." When the good are spotlighted, transgressions are concealed; when the "scoundrels" are appointed, crimes are punished. When

53. Several recessions of the text have 任舉 (“appointing and elevating”) instead of 任譽 ("appointing according to the reputation").

54. Jiang Lihong, following Zhu Shiche (朱師轍, 1878-1969), reads 鼠 as 處, “dwelling”; but I think he is wrong: the fact that "the rat" causes villainy to become unstoppable suggests that the original meaning is correct.

55. 辯慧, 亂之贊也; 禮樂, 淫佚之徵也; 慈仁, 過之母也; 任譽, 姦之鼠也。亂有贊 則行, 淫佚有徵則用, 過有母則生, 姦有鼠則不止。八者有群, 民勝其政;國無 八者，政勝其民。民勝其政，國弱;政勝其民，兵彊。故國有八者，上無以使守 戰, 必削至亡;國無八者, 上有以使守戰, 必興至王。SJS II.5: 35-36.

56. Following Zhu Shiche, I emend 復 with 覆. 


\section{Yuri Pines}

transgressions are concealed, the people overcome the law; when crimes are punished, the law overcomes the people. When the people overcome the law, the state is calamitous; when the law overcomes the people, the army is powerful. Hence it is said: "When the state employs the good people to rule scoundrels, it will be calamitous to the point of dismemberment; when the state employs scoundrels to rule the good people, it will be orderly ruled to the point of empowerment." ${ }^{57}$

Here the explanation is crucial for turning an appalling recommendation of "employing scoundrels to rule the good people" into an acceptable, even if disputable one: the authors explain that by speaking of "scoundrels" and the "good people" they simply refer to common erroneous definitions, according to which the selfish and the lawless are identified as "good" while the law-abiding people are "scoundrels." Once again, opponents may dispute the wisdom of Shang Yang's alternative definitions, but the common ground for the discussion had been established, and alienation of the readers from the text decreased.

On a few other occasions, the authors of "Explaining the people" make statements that may placate at least some of the opponents. Once they mention that "the nature of the people is to be orderly ruled; it is just that their affairs are calamitous." ${ }^{8}$ This statement implies that oppressive government corresponds in the final account to the people's "nature" (qing); it just helps the people to overcome calamity in their undertakings. ${ }^{59}$ Elsewhere the text echoes the "Eliminating the strong" chapter:

Punishments give birth to power; power gives birth to strength; strength gives birth to awesomeness; awesomeness gives birth to virtue: virtue is borne by punishments. ${ }^{60}$

This passage strongly resembles the maternal one; but it replaces the term "kindness" ( $h u i)$ with a more emotively attractive "virtue" (de). The connection between virtue and punishments is an old one, being already attested in the Zuo zhuan, if not earlier; usually both were conceived as mutually complementary. ${ }^{61}$ In the Book of Lord Shang punishments are clearly given a priority; but insofar as "virtue" (which in its meaning as "charisma" or "mana" may refer not just to

57. 用善, 則民親其親;任姦, 則民親其制。合而復之者, 善也; 別而規之者, 姦也。 章(彰)善則過匿, 任姦則罪誅。過匿則民勝法, 罪誅則法勝民。民勝法, 國亂;法 勝民, 兵疆。故曰: 以良民治, 必亂至削; 以姦民治, 必治至䮠。SJS II.5: 36 .

58. 民之情也治, 其事也亂。SJS II.5: 37.

59. The chapter further discusses the importance of the government's attentiveness to public opinion, an issue which is briefly — and enigmatically — outlined in the "Eliminating the strong" chapter. See SJS II.5: 40 and discussion of this passage in Lewis 1990: 93 and in Pines 2009: 206-207.

60. 刑生力, 力生彊, 彊生威, 威生德, 德生於刑。SJS II.5: 38 .

61. See Kominami 1992; Pines 2002: 126-128 and q.v. for further references. 
kindness but to the very right to rule) is considered a by-product of the punitive system, the elevation of punishments becomes less controversial. Once again, the discussion becomes more accommodative than in the "Eliminating the strong" chapter.

A similar, if less explicit tendency to soften the original message is observable in the second exegetical chapter, "Weakening the people." For instance it tries to justify the original postulate in favor of immoral warfare in the following way:

When there are affairs one is ashamed of doing, multiple scoundrels diminish; when the awards are not losing their constant, multiple scoundrels are stopped. ${ }^{62}$ When the enemy loses, it is surely beneficial; the army will attain utmost power and awesomeness. When there are no affairs one is ashamed of doing, it is beneficial to use the army; one who dwells for long in the position of benefit and power will surely become True Monarch. Hence, "he, whose army performs whatever the enemy dares not to perform, is strong; he, who in [military] affairs elevates whatever the enemy is ashamed of, benefits." 63

Possible textual corruption makes discussion of this passage difficult; Gao Heng assesses that the authors acknowledge the importance of the sense of shame in domestic affairs, while recommending that it be abandoned on the battlefield. ${ }^{64}$ I do not find strong textual support for this interpretation; but it seems clear at the very least that the authors do acknowledge a certain positive impact of the sense of shame. This view stands at odds with the phrase they are commenting upon ("he, who in [military] affairs elevates whatever the enemy is ashamed of, benefits"), and clearly causes awkwardness for their exegetical effort. Once again, we see an attempt - probably not entirely successful - to bridge the gaps with the more traditional or moral-minded audience, rather than to widen them.

Yet another chapter that is related to "Eliminating the strong" is "Making orders strict." Here the relations between the two and even their sequence are less evident; the latter chapter does not comment on the former but rather reproduces - either verbatim or with certain modifications - the statements of the former, adding at times new levels of discussion, especially with regard to proper appointments and with regard to the need to ensure full implementation of the laws. The "Making orders strict" chapter was furthermore reproduced with minor modifications in the Han Feizi, adding further complexity to its textual

62. The punctuation of this phrase and its meaning are hotly contested. I follow Gao Heng's glosses, especially in reading 疑 as 止.

63. 事有羞, 多姦寡; 賞無失, 多姦疑。敵失必利, 兵至彊威。事無羞, 利用兵, 久處利勢, 必王。故「兵行敵之所不敢行, 強;事興敵之所羞為, 利。SJS V.20: 122-123.

64. Gao Heng 1974: 157-158. 
history. For the purpose of the current discussion, I think we do have a hint of the relative earliness of "Eliminating the strong" in comparison to "Making orders strict." The former first introduces the "six parasites" ("year," "food," "beauty," "likes," "will," "conduct") and then discusses their negative impact on the state. The latter frequently employs the term "six parasites" without introducing it, probably presuming that the term is familiar to the audience. Only after a lengthy discussion of the damage caused by the six parasites do the authors explain:

Six parasites: rites and music, Odes and Documents, self-cultivation and goodness, filiality and fraternal duties, sincerity and trustworthiness, integrity and uprightness, benevolence and righteousness, negation of the army, being ashamed of waging war. When the state has these twelve, the superiors are unable to cause the people to engage in agriculture and warfare, and the state will surely be poor to the point of dismemberment. When the twelve come together, this is called: "the ruler's rule cannot overcome his ministers; the officials' rule cannot overcome their people"; this is called: "the six parasites overcome the government." ${ }_{65}$

In terms of harshness, this pronouncement equals those in early chapters discussed in the previous section; the list of virtues-turned-vices is even longer than before, and, just as in "Agriculture and warfare" and "Eliminating the strong" chapters, the reasons behind the selection of specific vices are not provided. This passage clearly contradicts my assessment that later layers in the Book of Lord Shang tend to be milder than earlier ones. However, if we take the "Making orders strict" chapter as a whole, the tendency toward moderation is apparent. Thus, when the author assaults employing "the good," his alternative is not to employ "scoundrels" but to appoint the people according to their merits (ren gong, SJS III.13: 77) - surely a much less controversial proposal! The accommodative spirit of the chapter is fully visible in its last passage:

The sage ruler understands the essentials of things. Hence in ordering the people he possesses the most essential; thus, he holds firmly rewards and punishments supporting thereby the One. [Benevolent is the one whose heart is affluent]. ${ }^{66}$ The

65. 六䖵: 禮樂, 曰詩書, 曰修善, 曰孝弟, 曰誠信, 曰貞廉, 曰仁義, 曰非兵, 曰差戰。國有十二者, 上無使農戰, 必貧至削。十二者成群, 此謂君之治不勝 其臣, 官之治不勝其民, 此謂六䩶勝其政也。SJS III.13: 80 .

66. The last sentence appears to be corrupt, and so possibly is the end of the previous one. I accept Jiang Lihong's punctuation and his substitution of 壹輔 with 輔壹 (Jiang suggests adding the word 教, as in chapter 3 of the Book of Lord Shang, but I am not convinced; $y i$ 喜 is frequently employed by Shang Yang as noun and not as an adjective; the One as the synonym of proper policy). For 仁者, 心之續也, I accept Gao Heng's substitute of 續 with 裕 (Gao Heng 1974: 109); but I also strongly suspect that this sentence is an old gloss that was inadvertently incorporated into the main text. 
sage ruler in ordering the men should first attain their heart; hence he is able to employ force. Force gives birth to strength; strength gives birth to awesomeness; awesomeness gives birth to virtue; virtue is born of force. The sage ruler is singularly possessive of it; hence he is able to implement benevolence and righteousness in All under Heaven. ${ }^{67}$

It is possible that this last section was added or modified at a later stage of the chapter's transmission; this assertion will explain why "benevolence and righteousness" which were anathematized just a few lines above are suddenly turned into the ultimate goal of the Sage's rule. Alternatively, it is possible that the difference between two appearances of the same term in both passages is that between faked and true "benevolence and righteousness": in the first case they refer to the moralizing discourse, which the Book of Lord Shang consistently views as detrimental to the state's prowess; in the second case, they refer to the reality of perfect order and peace which will be attained after merciless punishments and unrestrained warfare eliminate domestic and external foes. This is not the only passage in the Book of Lord Shang which promises that in the end morality will prevail after the author's program is fully implemented ( $c f$. "Drawing the policies" ["Hua ce"] chapter, SJS IV.18: 107); so the moralizing finale of "Making orders strict" may well belong to the original part of the chapter.

I shall not engage here in detailed analysis of each of the other chapters of the Book of Lord Shang, but rather summarize briefly. Not all of these chapters deal with the issues of morality and with the moralizing discourse; but those which do are markedly less abusive than chapters 3 and 4 cited in the previous section. Thus, "Opening the barred" presents an interesting narrative of the evolution of human society; according to this narrative, family values, benevolence, and "elevating the worthy" were indeed appropriate in the past, but are no longer fitting to the present age of violence and warfare ${ }^{68}$ Here, the moral means of ruling the people are negated just as elsewhere in the Book of Lord Shang, but this is done in an incomparably milder way than in, e.g., "Eliminating the Strong." Elsewhere, the "Drawing the policies" chapter (which may belong to a later layer of the book) explains:

Hence it is said: the benevolent can behave benevolently toward others but cannot cause them to behave benevolently; the righteous can love others, but cannot cause the others to be loving. From this I know that benevolence and righteousness are

67. 聖君知物之要, 故其治民有至要, 故執賞罰以壹輔（輔壹?）。仁者, 心之續 (裕?) 也。聖君之治人也, 必得其心, 故能用力。力生彊, 彊生威, 威生德, 德生於力。聖君獨有之, 故能述仁義於天下。SJS III.13: 82 .

68. For a detailed analysis of this chapter see Pines and Shelach 2005; Pines 2012. 
insufficient to rule All under Heaven... What is called "righteousness" is when ministers are loyal, sons filial, there is ritual order between the young and the old, and differences between men and women. Yet this is not the [real] righteousness. When the hungry cannot get food improperly, while the dying man cannot get life improperly: this is the constant of the Law. Sage kings did not esteem "righteousness" but esteemed the Law: laws must be clear; orders must be implemented-and that is all. ${ }^{69}$

These statements again bridge the gap between Shang Yang and his opponents. Morality is not condemned outright, but is presented as an inadequate means of policy-making; and the author also explains that when he rejects "righteousness" he simply rejects what is inaccurately understood as so, while his Law is certainly morally right. Time and again we observe a similar pattern: chapters composed at different stages during the formation of the book do not deviate from the fundamental message as expressed in its earliest layers but present it in a more appropriate, and, arguably, more "accommodative" way.

\section{Conclusion: clues about the formation of the Book of Lord Shang}

Let us summarize our findings. First, amid overall ideological consistency, the Book of Lord Shang presents two types of rhetoric: an alienating and abusive one in chapters 3 and 4 , and a more reasonable and accommodative one in most other chapters (chapter 13 is a mixed case). Second, in many, though not in all cases, it may be plausibly assumed that alienating rhetoric came first and was moderated in the later chapters. Third, it is highly unlikely that the differences among the chapters derive from different audiences; rather, all the chapters of the Book of Lord Shang were directed at both the ruler and a broader audience, viz. members of the educated elite of the state of Qin and by extension of the entire Zhou world.

If all these findings, tentative as they inevitably are, are correct, then an intriguing question can be posed. Why did the later editors and transmitters of the Book of Lord Shang not try to get rid of those radical statements which they considered counterproductive and which they tried to moderate through either exegesis or moderating additions? Was it not expedient for them to rewrite problematic sections of chapters 3,4 and 13 altogether and to make the text more acceptable and less abusive from the beginning? Clearly, they did not

69. 故曰: 仁者能仁於人, 而不能使人仁; 義者能愛於人, 而不能使人愛。是以知仁 義之不足以治天下也。…所謂義者, 為人臣忠, 為人子孝, 少長有禮, 男女有 別, 非其義也。餓不苟食, 死不苟生: 此乃有法之常也。聖王者, 不貴義而貴 法一一法必明, 令必行, 則已矣。SJS, IV.18: 113. 
feel comfortable with some of the book's statements, especially those of the "Eliminating the strong" chapter. Why then did they leave the chapter in its current, abusive form?

Two possible answers come to my mind. First, that the transmitters of, and contributors to, the Book of Lord Shang were genuinely in awe of the founder of their ideological current, Shang Yang, and dared not alter his original words. Yet the problem with this explanation is that it lacks any corroborative evidence. Shang Yang never became a towering figure for his followers on a par with Confucius, Mozi, or Laozi; even the one major thinker who did praise him-Han Feizi (d. 233 BCE) - is far from considering Shang Yang a Sage whose ideas are sacrosanct and whose legacy is inviolable. ${ }^{70}$ It is difficult to assume then that out of respect for the founder of the putative "Shang Yang current" his disciples and followers dared not alter his statements, even when these were detrimental to the successful appeal of his message among members of the elite.

Another more plausible explanation is that the disciples simply could not alter the text because it was too widespread. We are still wondering: how broadly did texts circulate during the Warring States period? Was there a small group of followers keeping the precious Ur-text and producing copies for a broader public? Or was circulation primarily in an oral form with a few loosely organized copies serving as an antecedent to the Song dynasty huaben books? Or rather the texts circulated in the written form, but, to avoid cumbersomeness, circulation was primarily confined to individual "chapters" (pian) rather than "books" as we know them from the Han dynasty onwards? ${ }^{71}$ It is not my intention here to engage comprehensively in these questions, nor do I believe that a definitive answer is currently possible. Yet it may be interesting to assess the possibility that "books" (i.e. multi-chapter compilations) attributed to a certain author already circulated as such during the Warring States period. ${ }^{72}$ If this circulation was broad enough, it would be much easier for the transmitters to add a section

70. For a critical, even if basically positive, assessment of Shang Yang by Han Feizi, see Han Feizi, "Ding fa" XVII.43: 957-965.

71. For a sample of debates on this topic, see Lewis 1999; Schaberg 2001; Boltz 2005; Kern 2005.

72. The earliest indisputable example of a large text that was prepared as a multi-chapter "book" is, arguably the Lüshi chunqiu (for the composition of which see Knoblock and Riegel 2000: 27-46). Yet it is possibly that Xunzi (ca 310-230 BCE) was among the first to deliberately disseminate his ideas in writing; Paul Goldin astutely observes that the chapters in the current text, compiled by Liu Xiang (d. 8 BCE) "fit so seamlessly that Xunzi could have only imagined his work as a coherent $2 u v r e$. Xunzi... represented a new breed of thinker, one who aimed, through writing, to influence diverse classes of readers across the land, most of whom he would never meet" (Goldin 2011a: 69). 
or a chapter rather than to omit one. This appears to be a plausible scenario for the circulation of the Book of Lord Shang.

There is one piece of evidence that may lend credibility to this scenario: Han Feizi's statement that "now everybody within the borders speaks of orderly rule; every family stores the laws of Shang [Yang] and Guan [Zhong]." 73 Surely, the statement is exaggerative by its nature; and, moreover, it is unclear whether "the laws of Shang Yang and Guan Zhong" refer to the texts associated with these statesmen or rather to a specific set of laws attributed to them. Yet whatever the details are, it is evident that by the end of the Warring States period, the renown of Shang Yang was higher and the circulation of the writings associated with him was broader than was the case from the Han dynasty onwards.

There is another indication that Shang Yang's writings circulated from a relatively early stage as "a book," rather than as individual chapters: namely the presence of two exegetical chapters on "Eliminating the strong." The existence of internal exegesis is not peculiar to the Book of Lord Shang (the Wu xing text from Guodian and Mawangdui comes immediately to my mind, but there are many other parallels, e.g. in Guanzi). ${ }^{74}$ While it is possible that originally exegetical chapters were transmitted orally, I think this is less likely in the case of the Book of Lord Shang, the chapters of which appear to me much less memorizable than, e.g., Confucius' or Laozi's maxims. If, then, exegetical writings accompanied the "Eliminating the strong" chapter from the early stage of its circulation, this presupposes at the very least circulation of a cluster of chapters together. It is not difficult to hypothesize that many chapters - an antecedent of the Book of Lord Shang as we know it - were already being circulated together in the Warring States period. In this case, excising problematic passages might have been more difficult than providing new commentaries and expanding the text. In my eyes, this is the most plausible scenario to explain the modification of rhetoric in the Book of Lord Shang.

This paper is just a first step toward reassessment of the nature of the Book of Lord Shang. Yet it suffices to indicate that paying attention to rhetorical devices may be helpful not just in clarifying the book's content and its potential impact but even in terms of understanding its internal structure. I hope that this will be a modest contribution towards the increased interest in political rhetoric in early Chinese texts.

73. 今境內之民皆言治, 藏商、管之法者家有之。Han Feizi, “Wu du” XIX.49: 1111 .

74. For some speculations about the earliest commentaries attached to the Master texts in the Warring States period, see, e.g., Pang Pu 2000. 


\section{BIBLIOGRAPHY}

Boesche, Roger (2008). "Kautilya's Arthashastra and the Legalism of Lord Shang." Journal of Asian History, no. 42.1: 64-90.

Boltz, William G. (2005). "The Composite Nature of Early Chinese Texts." In Kern, Martin (ed.), Text and Ritual in Early China. Seattle, University of Washington Press: 50-78.

Boshu Laozi jiaozhu 帛書老子校注 (1996). Compiled and annotated by Gao Ming 高 明. Beijing, Zhonghua shuju.

Brooks, E. Bruce and Brooks, A. Taeko (1998). The Original Analects: Sayings of Confucius and His Successors. New York, Columbia University Press.

CHEN, Li 陳澧 (2008) Dongshu dushuji 東塾讀書記. Repr. in Chen Li ji 陳澧集, compiled by Huang Guosheng 黄國聲. Shanghai, Shanghai guiji chubanshe: vol. 2, 1-352.

Creet, Herrlee G. (1953). Chinese Thought from Confucius to Mao Tse-tung. Chicago, University of Chicago Press.

Defoort, Carine (2001). "Ruling the World with Words: The Idea of zhengming in the Shizi." Bulletin of the Museum of Far Eastern Antiquities, no. 73: 217-242.

Defoort, Carine (2003). "Is There Such a Thing as Chinese Philosophy? Arguments of an Implicit Debate." Philosophy East and West, no. 51.3: 393-413.

DuYvendaK, J.J.-L., (transl.) (1928). The Book of Lord Shang: A Classic of the Chinese School of Law. Probsthain's Oriental Series 17. London, Probsthain.

Fischer, Markus (2012). "The Book of Lord Shang Compared with Machiavelli and Hobbes," Dao (forthcoming).

Fu, Zhengyuan (1996). China's Legalists: The Earliest Totalitarians and their Art of Ruling. Armonk and London, M.E. Sharpe.

GAO, Heng 高亨 (1974). Shang jun shu zhu yi 商君書注譯. Beijing, Zhonghua shuju.

Goldin, Paul R. (2011a). Confucianism. Durham, Acumen.

Goldin, Paul R. (2011b). "Persistent Misconceptions about Chinese 'Legalism."” Journal of Chinese Philosophy, no. 38.1: 64-80.

Goldin, Paul R. (compiler) (2011c). "Ancient Chinese Civilization: Bibliography of Materials in Western Languages." http://www.sas.upenn.edu/ealc/Ancient\%20 Chinese\% 20Civilization\%20Bibliography.pdf.

Graham, Angus C. (1989). Disputers of the Tao: Philosophical Argument in Ancient China. La Salle, IL, Open Court.

Guo, Moruo 郭沫若 (2008). “Qianqi fajia de pipan”前期法家的批判 [1945]. Repr. in Guo Moruo, Shi pipan shu 十批判書. Beijing, Zhongguo huaqiao chubanshe: 227-249.

Guoyu jijie 國語集解 (2002). Compiled by Xu Yuangao 徐元誥. Beijing, Zhonghua shuju.

Handelman, Don (1995). "Cultural Taxonomy and Bureaucracy in Ancient China: The Book of Lord Shang." International Journal of Politics, Culture, and Society, no. 9.2: 263-294. 


\section{Yuri Pines}

Han Feizi xin jiaozhu 韓非子新校注 (2000). Compiled by Chen Qiyou 陳奇猷. Shanghai, Guji chubanshe.

Han shu 漢書 (1997). By Ban Gu 班固 et al. Annotated by Yan Shigu 顏師古. Beijing, Zhonghua shuju.

Hu, Shi 胡適 (1996). Zhongguo zhexue shi dagang 中國哲學史大綱 [1919], Beijing, Dongfang chubanshe.

IkEDA, Tomohisa (2004). "The Evolution of the Concept of Filial Piety [xiao] in the Laozi, the Zhuangzi, and the Guodian Bamboo Text Yucong." In Chan, Alan K.L. and Tan, Sor-hoon (ed.). Filial Piety in Chinese Thought and History, London and New York, RoutledgeCurzon: 12-28.

Kandel, Jochen (1985). "Das Buch des Fürsten Shang und die Einführung der Monodoxie: Eine annotierte Übersetzung der Kapitel III und VIII des Shangchün shu." In Naudorf, Gert et al. (eds), Religion und Philosophie in Ostasien: Festschrift für Hans Steininger zum 65. Geburtstag. Würzburg, Königshausen + Neumann: 445-458.

KERn, Martin (2000). The Stele Inscriptions of Ch'in Shih-huang: Text and Ritual in Early Chinese Imperial Representation. New Haven, American Oriental Society.

Kern, Martin (2005). “The Odes in Excavated Manuscripts.” In Martin Kern (ed.), Text and Ritual in Early China. Seattle, University of Washington Press: 149-193.

Knoblock, John and Riegel, Jeffrey (transl.) (2000). The Annals of Lü Buwei: A Complete Translation and Study. Stanford, Stanford University Press.

Kominami, Ichirō 小南一郎 (1992). “Tenmei to toku”天命と德. Tōhō gakuhō 東方學 報, no. 64: 1-59.

LewIs, Mark E. (1990). Sanctioned Violence in Early China. Albany, State University of New York Press.

LEwIS, Mark E. (1999). Writing and Authority in Early China. Albany, State University of New York Press.

LewIs, Mark E. (2007). The Early Chinese Empires: Qin and Han. Cambridge, MA, Harvard University Press.

LI, Ling 李零 (2002). Guodian Chujian jiaodu ji 郭店楚簡校讀記. Beijing, Beijing daxue chubanshe, rev. edition.

LI, Yu-ning (ed.) (1977). Shang Yang's Reforms and State Control in China. White Plans, NY, Sharpe.

LIANG, Qichao 梁啟超 (1996). Xian Qin zhengzhi sixiang shi 先秦政治思想史 [1919]. Repr. Beijing, Dongfang.

Lin, Yü-sheng (1979). The Crisis of Chinese Consciousness: Radical Antitraditionalism in the May Fourth Era. Madison and London, University of Wisconsin Press.

Liu, Chunhua 劉春華 (2005). “Cong ‘Shiji’ kan Qin ren de minzu guan” 從《史記》 看秦人的民族觀. Qin wenhua luncong 秦文化論叢, no. 12: 393-407.

Liu, Yutao 劉雨濤 (1988). “Qin yu Huaxia wenhua” 秦與華夏文化, Kongzi yanjiu 孔 子研究, no. 2: 61-67.

Luo, Genze 羅根澤 (2001). “Shang jun shu tanyuan” 《商君書》探源 [1935], repr. in Luo Genze, Luo Genze shuo zhuzi 羅根澤說諸子, compiled by Zhou Xunchu 周 勛初. Shanghai, Shanghai guji chubanshe: 369-380. 
Lüshi chunqiu jiaoshi 呂氏春秋校釋 (1990). Compiled and annotated by Chen Qiyou 陳奇猷. Shanghai, Xuelin.

Major, John S., Queen, Sarah A., Meyer, Andrew Seth and Roth, Harold D. (transl. and eds) (2010). The Huainanzi: A Guide to the Theory and Practice of Government in Early Han China. New York, Columbia University Press.

MENG, Wentong 蒙文通 (1936). “Qin wei Rong zu kao” 秦為戎族考, Yu gong 禹貢, no. 6.7: 17-20.

Mozi jiaozhu 墨子校注 (1994). Compiled and annotated by Wu Yujiang 吳毓江. Beijing, Zhonghua shuju.

Nivison, David S. (1999). "The Classical Philosophical Writings.” In Loewe, Michael and Shaughnessy, Edward L. (eds), The Cambridge History of Ancient China. Cambridge, Cambridge University Press: 352-544.

PANG, Pu (2000). "A Comparison of the Bamboo Slip and the Silk Manuscript $W u$ Xing," Contemporary Chinese Thought, no. 32.1: 50-57.

PINEs, Yuri (2002). Foundations of Confucian Thought: Intellectual Life in the Chunqiu Period, 722-453 BCE. Honolulu, University of Hawaii Press.

PINES, Yuri (2005/6). "Biases and Their Sources: Qin History in the Shiji," Oriens Extremus, no. 45: 10-34.

PInEs, Yuri (2009). Envisioning Eternal Empire: Chinese Political Thought of the Warring States Era. Honolulu, University of Hawai'i Press.

PINES, Yuri (2012). "From Historical Evolution to the End of History: Past, Present and Future from Shang Yang to the First Emperor." In Goldin, Paul (ed.), Dao Companion to the Philosophy of Han Fei. Berlin, Springer.

PInes, Yuri and Shelach, Gideon (2005). "Using the Past to Serve the Present': Comparative Perspectives on Chinese and Western Theories of the Origins of the State." In Shaked, Shaul (ed.), Genesis and Regeneration: Essays on Conceptions of Origins. Jerusalem, The Israel Academy of Science and Humanities: 127-163.

Pines, Yuri, Falkenhausen, Lothar von, Shelach, Gideon and Yates, Robin D.S. (eds) (forthcoming). The Birth of Empire: The State of Qin revisited. Berkeley, University of California Press.

QIAN, Mu 錢 穆 (2001). Xian Qin zhuzi xi nian 先秦諸子繫年 [1935]. Repr. Beijing, Shangwu yinshuaguan.

QI, Sihe 齊思和 (2001). “Shang Yang bianfa kao”商鞅變法考 [1947]. Repr. in Qi Sihe, Zhongguo shi tanyan 中國史探研. Shijiazhuang, Hebei jiaoyu chubanshe: 247-278.

Rubin, Vitaly (1976). Individual and State in Ancient China. New York, Columbia University Press.

Schaberg, David C. (2001). A Patterned Past: Form and Thought in Early Chinese Historiography. Cambridge, MA, Harvard University Asia Center.

SCHIFFrIn, Harold Z. (1968). Sun Yat-sen and the Origins of the Chinese Revolution. Berkeley, University of California Press.

Schwartz, Benjamin I. (1985). The World of Thought in Ancient China. Cambridge, MA, Harvard University Press. 


\section{Yuri Pines}

Shang jun shu zhuizhi 商君書錐指 (1996). Annotated by Jiang Lihong 蔣禮鴻. Beijing, Zhonghua shuju.

Shelach, Gideon and Pines, Yuri (2005). "Power, Identity and Ideology: Reflections on the Formation of the State of Qin (770-221 BC)." In Stark, Miriam (ed.), An Archaeology of Asia. Malden, MA, Blackwell: 202-230.

Shiji 史記. By Sima Qian 司馬遷 et al. (1997). Annotated by Zhang Shoujie 張守節, Sima Zhen 司馬貞, and Pei Yin 裴䭾. Beijing, Zhonghua shuju.

Shimada Kenji (1990). Pioneer of the Chinese Revolution: Zhang Binglin and Confucianism. Stanford, CA, Stanford University Press.

Stevenson, Charles L. (1938). "Persuasive Definitions.” Mind, no. 47: 331-350.

Su, Shi 蘇軾. Dongpo quanji 東坡全集. E-Siku quanshu edition.

Tong, Weimin 全衛敏 (2007). Shang jun shu yanjiu 商君書研究. Ph.D. diss., Beijing shifan daxue.

YANG, Xiaoshan (2007). "Wang Anshi's 'Mingfei qu' and the Poetics of Disagreement." Chinese Literature: Essays, Articles, Reviews, no. 29: 55-84.

Yosнiмото, Michimasa 吉本道雅 (2000). “Shō Kun henhō kenkyū josetsu” 商君變法 研究序說, Shirin 史林, no. 83-84: 1-29.

YoshinAmI, Takashi 好并隆司 (1992). Shōkunsho kenkyū 商君書研究. Hiroshima, Keisuisha.

ZENG, Zhenyu 曾振宇 (2003). “Lishi de Shang Yang yu fuhaohua de Shang Yang”歷史 的商鞅與符號化的商鞅, Qilu xuekan 齊鲁學刊, no. 6: 115-120.

ZhANG, Jue 張覺 (2006). Shang jun shu jiaozhu 商君書校注. Changsha: Yuelu shushe. ZHANG, Linxiang 張林祥 (2008). “Shang jun shu” de chengshu yu sixiang yanjiu 《商 君書》的成書與思想研究. Beijing, Renmin chubanshe.

Zhanguo ce zhushi 戰國策注釋 (1991). Annotated by He Jianzhang 何建章. Beijing, Zhonghua shuju.

ZHAO, Yuzhuo 趙玉卓 (2010). “Gaige kaifang yilai Shang jun shu yanjiu zongshu” 改 革開放以來《商君書》研究綜述. Taiyuan chengshi zhiye jishu xueyuan xuebao 太原城市職業技術學院學報, no. 1: 52-53.

ZHENG, Liangshu 鄭良樹 (1989). Shang Yang ji qi xuepai 商鞅及其學派. Shanghai, Guji chubanshe.

Zhuangzi jinzhu jinyi 莊子今注今譯 (1994). Annotated by Chen Guying 陳鼓應. Beijing, Zhonghua shuju. 


\section{GLOSSARY}

“Chi ling” 飭令

“Cuo fa” 錯法

de 德

“Ding fen” 定分

Geming jun 革命軍

Guan Zhong 管仲

Guanzi 管子

Guodian 郭店

Han 漢

Han Feizi 韓非子

hao jie 豪傑

huaben 話本

“Hua ce”畫策

Huainanzi 淮南子

hui 惠

“Jin ling” 靳令

“Jing nei”境內

jun 君

"Kai sai”開塞

“Ken ling” 墾令

King Huiwen of Qin 秦惠文王

“Lai min" 徠民

Laozi 老子

Liu Xiang 劉向

Lord Xiao of Qin 秦孝公

Lüshi chunqiu 呂氏春秋

Mai Menghua 麥夢華

Mao Zedong 毛澤東

Mawangdui 馬王堆

Meng Wentong 蒙文通

Mozi 墨子

“Nong zhan”農戰

pian 篇

Qin 秦

qing 情

“Qu qiang” 去彊

ren gong 任功

Rong 戎

“Ruo min” 弱民

Shang jun shu 商君書

“Shang xing” 賞刑 


\section{Yuri Pines}

Shang Yang 商鞅

Shen Buhai 申不害

“Shuo min" 說民

Sima Qian 司馬遷

Su Shi 蘇軾

Tianzi 天子

wang 王

Wang Anshi 王安石

wang dao 王道

wang zhe 王者

Wu xing 五行

“Wuyi” 無義

xue pai 學派

Xunzi 荀子

yi 壹

Zhang Binglin 章炳麟

Zhanguo 戰國

Zhou 周

zhu 主

Zhuangzi 莊子

Zou Rong 贸容

Zuo zhuan 左傳 